J. Dairy Sci. 99:3445-3456

http://dx.doi.org/10.3168/jds.2015-10110

(C) American Dairy Science Association ${ }^{\circledR}, 2016$.

\title{
Increasing linseed supply in dairy cow diets based on hay or corn silage: Effect on enteric methane emission, rumen microbial fermentation, and digestion
}

\author{
C. Martin, ${ }^{*}{ }^{1}$ A. Ferlay, ${ }^{*} \dagger$ P. Mosoni, $\ddagger$ Y. Rochette,${ }^{*} \dagger$ Y. Chilliard,${ }^{*} \dagger$ and M. Doreau ${ }^{*} \dagger$ \\ *INRA, UMR1213 Herbivores, F-63122 Saint-Genès-Champanelle, France \\ †Clermont Université, VetAgro Sup, UMR Herbivores, BP 10448 F-63000 Clermont-Ferrand, France \\ fINRA, UR454 Microbiologie, F-63122 Saint-Genès-Champanelle, France
}

\begin{abstract}
We investigated the effects of increasing extruded linseed supply in diets based on hay ( $\mathrm{H}$; experiment 1$)$ or corn silage (CS; experiment 2) on enteric methane $\left(\mathrm{CH}_{4}\right)$ emission, rumen microbial and fermentation parameters, and rumen and total-tract digestibility. In each experiment, 4 lactating Holstein cows fitted with cannulas at the rumen and proximal duodenum were used in a $4 \times 4$ Latin square design (28-d periods). Cows were fed ad libitum a diet [50:50 and 60:40 forage:concentrate on a dry matter (DM) basis for experiments 1 and 2, respectively] without supplementation (H0, CS0) or supplemented with extruded linseed at 5\% (H5, CS5), 10\% (H10, CS10), and 15\% (H15, CS15) of dietary DM (i.e., 1.8, 3.6 and $5.4 \%$ total fatty acids added, respectively). All measurements were carried out during the last $8 \mathrm{~d}$ of each period. Linseed supply linearly decreased daily $\mathrm{CH}_{4}$ emission in cows fed $\mathrm{H}$ diets (from 486 to $289 \mathrm{~g} / \mathrm{d}$ for H0 to H15, on average) and CS diets (from 354 to $207 \mathrm{~g} / \mathrm{d}$ for CS0 to CS15, on average). The average decrease in $\mathrm{CH}_{4}$ per kilogram of DM intake was, respectively, $-7,-15$, and $-38 \%$ for H5, H10, H15 compared with the H0 diet, and $-4,-8$, and $-34 \%$ for CS5, CS10, and CS15 compared with the CS0 diet. The same dose-response effect was observed on $\mathrm{CH}_{4}$ emission in percent of gross energy intake, per kilogram of nutrient digested, and per kilogram of $4 \%$ fat- and $3.3 \%$ protein-corrected milk (FPCM) in both experiments. Changes in the composition of rumen volatile fatty acids in response to increasing linseed supply resulted in a moderate or marked linear decrease in acetate:propionate ratio for $\mathrm{H}$ or CS diets, respectively. The depressive effect of linseed on total protozoa concentration was linear for $\mathrm{H}$ diets $(-15$ to $-40 \%$, on average, for H5 to H15 compared with H0)
\end{abstract}

Received July 13, 2015.

Accepted January 6, 2016.

${ }^{1}$ Corresponding author: cecile.martin@clermont.inra.fr and quadratic for CS diets ( -17 to $-83 \%$, on average, for CS5 to CS15 compared with CS0). Concentration of methanogens was similar among $\mathrm{H}$ or CS diets. The energetic benefits from the decreased $\mathrm{CH}_{4}$ emission with linseed supply in diets based on hay or corn silage did not improve digestibility or milk yield. Milk efficiency ( $\mathrm{kg}$ of $\mathrm{FPCM} / \mathrm{kg}$ of DM intake) was improved with linseed supply up to $\mathrm{H} 10$ in $\mathrm{H}$ diets and was unchanged in CS diets. Lower $\mathrm{CH}_{4}$ enteric emission from dairy cows fed linseed helps limit the environmental footprint of ruminant livestock.

Key words: dairy cow, digestion, hay or corn silage, linseed, methane

\section{INTRODUCTION}

Methane $\left(\mathrm{CH}_{4}\right)$ released by ruminants is the main greenhouse gas at the farm level (Veysset et al., 2010) and constitutes an energetic loss for the animal ranging from 2 to $12 \%$ of its gross energy (GE) intake (Johnson and Johnson, 1995). Decreasing enteric $\mathrm{CH}_{4}$ emission from ruminants without altering animal production is desirable both as a strategy to reduce global greenhouse gas emissions, and thus the negative environmental impact of livestock, and as a means of improving feed conversion efficiency.

Several reviews have reported that dietary fatty acid (FA) supply (Grainger and Beauchemin, 2011; Hristov et al., 2013), particularly FA from linseed (Martin et al., 2010), is one of the most efficient dietary strategies to mitigate enteric $\mathrm{CH}_{4}$ emission from dairy cows. In addition, linseed supply to dairy cow diets helps improve the nutritional value of milk through a slight increase in linolenic acid (Doreau et al., 2011). The extent of the linseed $\mathrm{CH}_{4}$-mitigating effect varies depending on many factors, including FA availability in the rumen and the dose included in the diet (Martin et al., 2010). Low supply of linseed oil ( $<2 \%$ added FA) did not modulate $\mathrm{CH}_{4}$ emission in dairy cows (Livingstone et al., 2015), whereas higher supply (3.7-5.7\% added FA) of differ- 
ent linseed forms (crude, crushed, or extruded whole grains, or oil) resulted in a lower $\mathrm{CH}_{4}$ yield $(\mathrm{g} / \mathrm{kg}$ of DM intake) but had deleterious effects on OM and fiber digestibility and, for the highest FA level, impaired intake and dairy cow performance (Martin et al., 2008; Beauchemin et al., 2009b). In addition, the extent of the effect of linseed supply on $\mathrm{CH}_{4}$ emission may also depend on diet composition, especially the nature of forage and the percentage of concentrate (Martin et al., 2010). Only Chung et al. (2011) compared the effect of linseed with different forage-based diets fed to dry cows, and found a decrease in $\mathrm{CH}_{4}$ emission with barley silage, but not with hay. To our knowledge, the doseresponse effect of dietary linseed $\mathrm{FA}$ on $\mathrm{CH}_{4}$ emission has not yet been studied. In addition, only a few in vivo studies have considered, in the same experiment, the effects of linseed FA supply on both $\mathrm{CH}_{4}$ emission and the rumen fermentation and microbial processes involved.

To address these questions, we performed 2 experiments in dairy cows, the first with a hay-based diet and the second with a corn silage-based diet. These diets are representative of winter diets used frequently in Europe for dairy cows. Diets were supplemented with extruded linseed at 3 levels of FA supply $(1.8,3.6$, and $5.4 \%$ of DM). The highest FA supply used here is not currently recommended at the farm level, but the wide variation in FA level was chosen to establish the dose-response relationship regarding enteric $\mathrm{CH}_{4}$ emission and associated digestive processes such as rumen fermentation and microbial parameters and rumen and total-tract digestibility of diets. Data on milk production and composition have been published previously (Ferlay et al., 2013).

\section{MATERIALS AND METHODS}

Two experiments were performed during 2 successive years at the animal experimental facilities of the Herbivores Research Unit at Institut National de la Recherche Agronomique (INRA, Saint-Genès-Champanelle, France). Procedures on animals were in accordance with the guidelines for animal research of the French Ministry of Agriculture and all other applicable national and European guidelines and regulations for experimentation with animals (see http://www2.vetlyon.fr/ens/expa/acc_regl.html for details).

\section{Animals, Experimental Design, and Diets}

The main description of the experiments are given below. Additional details are found in Ferlay et al. (2013). In each experiment, 4 lactating multiparous Holstein cows fitted with rumen and proximal duodenum cannulas were used after lactation peak (experiment 1: $117 \pm 26$ DIM; experiment 2: $96 \pm 29$ DIM) in $4 \times 4$ Latin square designs. Each experimental period lasted $28 \mathrm{~d}$ with the first $5 \mathrm{~d}$ as a transition period between treatments and the last $8 \mathrm{~d}$ in wk 4 (d 1 to 8 ) as a measurement period. Cows were housed in a tiestall barn during the whole experiment.

Linseeds were supplied as extruded linseed mixture (70\% linseed, 30\% wheat bran, Valorex, Combourtillé, France) at $0,7,14$, or $21 \%$ of inclusion in the diet, which represented $0,5,10$, or $15 \%$ of linseed in dietary DM. This mixture was included in the diets substituting for expeller linseed meal, wheat bran, and corn grain, and it provided a supply level of $1.8,3.6$, or $5.4 \%$ FA for 5,10 , and $15 \%$ of linseed, respectively. In experiment 1 , the diet was composed of $50 \%$ hay and $50 \%$ concentrates on a DM basis; the experimental diets were called Ho, H5, H10, and H15, according to the level of inclusion of linseeds. In experiment 2, the diet was composed of $60 \%$ forages ( $55.5 \%$ corn silage plus $4.5 \%$ hay) and $40 \%$ concentrates on a DM basis; experimental diets were called CS0, CS5, CS10, and CS15 according to the level of inclusion of linseeds. Diets were given ad libitum. In both experiments, concentrates were offered at 60 and $40 \%$ of the daily amount at 0900 and $1630 \mathrm{~h}$, respectively. In experiment 1 , hay was offered in equal amounts at 0900, 1330, and $1630 \mathrm{~h}$. In experiment 2, forages was offered in equal amounts at 0900 and 1630 $\mathrm{h}$. The forage:concentrate ratio was maintained as close as possible to the target by adjusting the amount of feed offered daily. Ingredient and chemical composition of experimental diets as consumed are presented in Table 1 . The diets were formulated to cover $105 \%$ of the INRA energy and protein requirements for maintenance and lactation of dairy cows (INRA, 2007).

\section{Measurements}

Intake, Milk Production, and BW. Intake and milk production were recorded daily by weighing throughout the experiment. Feeds (offered and refused) and milk were sampled in wk 4 until biochemical analyses as described in Ferlay et al. (2013). Animals were weighed at the beginning and the end of the experiment.

Total-Tract and Rumen Digestibility. Totaltract digestibility was measured by total feces collection from d2 to d7 of each experimental period. Duodenal flow was determined using ytterbium chloride $\left(\mathrm{YbCl}_{3}\right)$ as described by Fanchone et al. (2013). Briefly, a $\mathrm{YbCl}_{3}$ solution was infused continuously into the rumen $(1.2 \mathrm{~g}$ of $\mathrm{Yb}$ daily) via the rumen cannula using a peristaltic 
Table 1. Composition of experimental diets as consumed based on hay (H; experiment 1 ) or corn silage (CS; experiment 2) without supplemented extruded linseed (H0, CS0) or supplemented with extruded linseed at 5\% (H5, CS5), 10\% (H10, CS10) or 15\% (H15, CS15) of dietary DM

\begin{tabular}{|c|c|c|c|c|c|c|c|c|}
\hline \multirow[b]{2}{*}{ Item } & \multicolumn{4}{|c|}{$\begin{array}{c}\text { Hay-based } \\
\text { diet (experiment 1) }\end{array}$} & \multicolumn{4}{|c|}{$\begin{array}{l}\text { Corn silage-based } \\
\text { diet (experiment 2) }\end{array}$} \\
\hline & H0 & H5 & H10 & H15 & $\mathrm{CS} 0$ & CS5 & CS10 & CS15 \\
\hline \multicolumn{9}{|l|}{ Ingredient, $\%$ of $\mathrm{DM}$} \\
\hline Hay $^{1}$ & 49.6 & 49.3 & 49.4 & 50.2 & 4.5 & 4.4 & 4.3 & 4.8 \\
\hline Corn silage $^{2}$ & 0 & 0 & 0 & 0 & 55.7 & 55.6 & 55.3 & 55.4 \\
\hline Dairy concentrate $^{3}$ & 27.7 & 27.9 & 27.7 & 27.3 & 12.1 & 11.7 & 12.1 & 11.6 \\
\hline Wheat bran & 6.3 & 4.2 & 2.1 & 0 & 6.0 & 4.1 & 1.8 & 0 \\
\hline Linseed meal & 9.2 & 6.2 & 3.1 & 0 & 8.8 & 6.0 & 3.3 & 0 \\
\hline Extruded linseed:wheat bran (70:30) & 0 & 7.0 & 14.1 & 20.8 & 0 & 7.1 & 14.2 & 21.2 \\
\hline Mineral-vitamin $\operatorname{mix}^{4}$ & 0.8 & 0.9 & 0.9 & 0.9 & 1.0 & 1.0 & 1.0 & 1.1 \\
\hline \multicolumn{9}{|l|}{ Chemical composition, \% of DM } \\
\hline OM & 92.1 & 92.1 & 92.1 & 93.1 & 92.6 & 92.9 & 93.2 & 93.7 \\
\hline $\mathrm{NDF}$ & 46.8 & 47.1 & 47.6 & 48.5 & 40.5 & 41.5 & 42.4 & 43.6 \\
\hline
\end{tabular}

${ }^{1}$ Hay (\% of DM): OM (92.5), NDF (61.9), ADF (31.4), nitrogen (1.3), FA (1.1) for experiment 1; OM (93.3), NDF (63.5), ADF (36.8), nitrogen (1.3), FA (1.2) for experiment 2.

${ }^{2}$ Corn silage (\% of DM): OM (95.2), NDF (49.7), ADF (24.5), starch (31.0), nitrogen (1.2), FA (2.6) for experiment 2.

${ }^{3}$ Dairy concentrate (\% of DM): OM (92.3), NDF (31.1), ADF (10.7), starch (28.1), nitrogen (2.9), FA (1.4) for experiment 1; OM (92.3), NDF (24.2), ADF (11.0), starch (26.5), nitrogen (2.9), FA (1.2) for experiment 2.

${ }^{4}$ Minerals (\%), P (0.8), Ca (1), Mg (0.5), Na (0.5), Cu (0.015); trace elements (mg/kg): Cu (15); vitamins (IU/kg): vitamin A (6,000), vitamin $\mathrm{D}_{3}(1,250)$, and vitamin $\mathrm{E}(10 \mathrm{mg} / \mathrm{kg})$.

pump from $6 \mathrm{~d}$ before duodenal samplings to $\mathrm{d} 6$ to ensure a steady state before sampling. Sixteen 250-mL duodenal samples were collected day and night from d 5 to 7 and then pooled, providing representative samples of duodenal contents, which were frozen at $-20^{\circ} \mathrm{C}$. After thawing, subsamples were used for nitrogen $(\mathrm{N})$ and ammonia $\mathrm{N}\left(\mathrm{N}_{-} \mathrm{NH}_{3}\right)$ determination, and the rest of the sample was lyophilized for OM, NDF, ADF, starch, and $\mathrm{Yb}$ determination. Feces were separated from urine by a device diverting urine in a bottle, removed once daily, and then weighed and mixed. A $1 \%$ feces aliquot was sampled for DM determination $\left(60^{\circ} \mathrm{C}\right.$ for $\left.72 \mathrm{~h}\right)$ and then pooled for the whole period, and was kept for OM, $\mathrm{NDF}, \mathrm{ADF}$, starch, and $\mathrm{Yb}$ determinations. A $0.5 \%$ feces aliquot was sampled for $\mathrm{N}$ and $\mathrm{Yb}$ determination and frozen at $-20^{\circ} \mathrm{C}$ until analyses.

Methane Emission. Methane emission was determined from d 1 to 4 according to the sulfur hexafluoride $\left(\mathrm{SF}_{6}\right)$ tracer technique described by Martin et al. (2008). Brass permeation tubes were filled with appoximately $600 \mathrm{mg}$ of $\mathrm{SF}_{6}$ gas while tubes were kept in liquid $\mathrm{N}_{2}$ and then calibrated for 10 wk. Permeation rates of tubes averaged $1.720 \pm 0.318 \mathrm{mg} / \mathrm{d}$ for experiment 1 and $1.334 \pm 0.319 \mathrm{mg} / \mathrm{d}$ for experiment 2 . Tubes were introduced in the rumen 2 wk before the beginning of measurements and remained in the rumen throughout the experiment. Representative breath samples of each animal were collected daily in evacuated collection devices by a capillary tubing fitted to a halter. Ambient air samples were collected once daily in the shed during the $4 \mathrm{~d}$ of sampling breath gas.

Rumen Fermentation Parameters and Microbial Ecosystem. On d 6 and 7, $300 \mathrm{~g}$ of rumen contents were collected by hand from different sites of the rumen just before and $2.5 \mathrm{~h}$ after the morning feeding. Samples were immediately strained through a $250-\mu \mathrm{m}$-pore nylon filter to obtain rumen liquid and solid phase fractions. The liquid phase was used for $\mathrm{pH}$ determination using a digital $\mathrm{pH}$ meter (CG837, Ag/ $\mathrm{AgCl}$ electrode, Schott Geräte, Hofheim, Germany) and then sampled as follows. First, $0.5 \mathrm{~mL}$ of $5 \% \mathrm{H}_{3} \mathrm{PO}_{4}$ was added to a 5 -mL sample and then frozen before VFA analysis. Then, $4 \mathrm{~mL}$ of $20 \% \mathrm{NaCl}$ were added to a 1-mL sample and frozen before $\mathrm{N}-\mathrm{NH}_{3}$ determination. Five milliliters of a methyl green-formalin-salt solution (0.92 $\mathrm{m} M$ methyl green, $0.14 M$ sodium chloride, 35 $\mathrm{mL} / \mathrm{L}$ formaldehyde) were added to a $5-\mathrm{mL}$ sample and shielded from light at room temperature until protozoa counting. In addition, before feeding, a 10-mL sample of liquid phase and a $30-\mathrm{g}$ sample of solid phase were 
stored without preservative in sterile tube at $-20^{\circ} \mathrm{C}$ (Mosoni et al., 2007) until microbial analyses by quantitative PCR (qPCR).

\section{Analyses}

Biochemical Analyses. Organic matter was determined by ashing at $550^{\circ} \mathrm{C}$ for $6 \mathrm{~h}, \mathrm{~N}$ by the Kjeldahl procedure, and starch using a polarimetric method (AOAC International, 1997). Fiber (NDF and ADF) was determined by sequential procedure (Van Soest et al., 1991) after pretreatment with amylase and was expressed inclusively of residual ash. Gross energy was determined using an adiabatic bomb calorimeter (Gallenkamp Autobomb; Loughborough, UK).

Ytterbium was determined in feces and duodenal contents by atomic absorption spectrophotometry (model 2380 spectrophotometer, PerkinElmer, Waltham, MA) at a wavelength of $398.8 \mathrm{~nm}$ with an acetylene $/ \mathrm{N}_{2} \mathrm{O}$ flame after extraction of the marker from lyophilized samples (Hart and Polan, 1984). Duodenal DM flow was calculated from fecal DM output and $\mathrm{Yb}$ concentrations in duodenum and feces.

Concentrations of $\mathrm{SF}_{6}$ and $\mathrm{CH}_{4}$ in breath and ambient air samples were determined by gas chromatography as described by Martin et al. (2008). A gas chromatograph (Varian-Chrompack, CP-9003, Les Ulis, France) fitted with an electron capture detector and a gas chromatograph (PerkinElmer; Autosystem XL, Courtaboeuf, France) fitted with a flame-ionization detector were used to determine $\mathrm{SF}_{6}$ and $\mathrm{CH}_{4}$ concentrations, respectively. The samples were run on chromatographs equipped either with a Molecular Sieve $0.5 \mathrm{~nm}$ column $(3 \mathrm{~m} \times 3.2 \mathrm{~mm}$ internal diameter; Interchim, Montluçon, France) maintained at $60^{\circ} \mathrm{C}$ for the $\mathrm{SF}_{6}$ analysis or with a Porapak N 80-100 mesh column $(3 \mathrm{~m} \times 3.2$ $\mathrm{mm}$ internal diameter; Alltech, Templemars, France) maintained at $40^{\circ} \mathrm{C}$ for the $\mathrm{CH}_{4}$ analysis. Flow rate of the carrier gases was $30 \mathrm{~mL} / \mathrm{min}$ of $\mathrm{N}_{2}$ and $40 \mathrm{~mL} /$ min of helium for the $\mathrm{SF}_{6}$ and the $\mathrm{CH}_{4}$ analyses, respectively. Chromatographic analyses were performed after calibration with standard gases (Air Liquide, Mitry-Mory, France) for $\mathrm{SF}_{6}$ (195 ppt) and $\mathrm{CH}_{4}$ (99.9 ppm). Daily $\mathrm{CH}_{4}$ emission by each animal was calculated using the permeation rate of $\mathrm{SF}_{6}$ for each animal and the concentrations (above background) of $\mathrm{SF}_{6}$ and $\mathrm{CH}_{4}$ in the breath samples, as follows: $\mathrm{CH}_{4}(\mathrm{~g} / \mathrm{d})=$ $\mathrm{SF}_{6}$ permeation rate $(\mathrm{g} / \mathrm{d}) \times\left[\mathrm{CH}_{4}\right] /\left[\mathrm{SF}_{6}\right]$, where gas concentrations are expressed in micrograms per cubic meter.

Volatile fatty acids were analyzed in rumen fluid by gas chromatography (CG 8000 gas chromatography, Carlo Erba Instruments, Milan, Italy) using a fusedsilica column (length $25 \mathrm{~m}$, inner diameter $0.25 \mathrm{~mm}$ )
CP-wax 58 FFAP CB (Varian, Middelburg, the Netherlands) and 4-methylvaleric acid as internal standard (Jouany, 1982). Ammonia $\mathrm{N}$ was determined in rumen fluid and duodenal contents by the colorimetric method of Weatherburn (1967) using an autoanalyzer (System II, Technicon Instruments, Tarrytown, NY).

Microbial Analyses. Total DNA was extracted in duplicate from 1-mL liquid and 0.250-g solid phases of the rumen content using the method described by $\mathrm{Yu}$ and Morrison (2004). Major cellulolytic bacteria-Fibrobacter succinogenes, Ruminococcus flavefaciens and Ruminococcus albus - as well as methanogenic Archaea were quantified by targeting $r r s$ and $m c r A$ genes, respectively, using the qPCR conditions described by Mosoni et al. (2011). Data were expressed as copy number of target gene per microgram of DNA. Protozoal numbers in the rumen fluid (cells $/ \mathrm{mL}$ ) were counted by microscopy using a Dolfuss cell (Elvetec Services, Clermont-Ferrand, France) according to the procedure described in Jouany and Senaud (1982) and were categorized as either entodiniomorphs or holotrichs ciliates (Williams and Coleman, 1992).

\section{Statistical Analyses}

Before statistical analyses, data of each variable collected on several days in wk 4 were averaged and microbial data were $\log _{10}$ transformed to achieve normal distribution of the residuals. For each experiment, data were analyzed as $4 \times 4$ Latin squares using the Mixed procedure of SAS (SAS Institute, 2003). The statistical models included the random effect of cow and fixed effects of period $(\mathrm{n}=4)$, diet $(\mathrm{n}=4)$ for some variables (intake, milk production, $\mathrm{CH}_{4}$ emission, digestibility and microbial qPCR), and sampling time $(\mathrm{n}=2)$ and the interaction diet $\times$ sampling time for repeated variables (rumen fermentation and protozoa). Variance component was the covariance structure used in both models. Linear and quadratic contrast statements were used to test the effect of increasing amounts of extruded linseed. Linear or quadratic effects are denoted as $P_{L}$ or $P_{Q}$, respectively. Least squares means are reported with the standard error of the mean derived from the model. Data were considered significant if $P \leq 0.05$ and trends were presented at $0.05<P<0.10$.

\section{RESULTS}

\section{Experiment 1}

Final BW of cows was similar to initial BW (655 \pm 68.2 and $655 \pm 55.0 \mathrm{~kg}$, respectively) in experiment 1. Increasing supply of extruded linseed in the haybased diets did not significantly modify intake of DM, 
OM, NDF, N, or GE (Table 2), whereas starch intake decreased linearly with linseed supply $\left(P_{L}<0.001\right)$. Milk yield and $4 \%$ fat- and $3.3 \%$ protein-corrected milk (FPCM) were similar among diets based on hay, whereas a curvilinear decrease was reported for milk efficiency ( $\mathrm{kg}$ of $\mathrm{FPCM} / \mathrm{kg}$ of DMI; $P_{Q}=0.04$ ), the lowest value being reported for $\mathrm{H} 15$ and the highest for H10 (Table 2).

Nutrient digestibilities in the rumen (DM, OM, NDF) and NAN duodenal flow were unaffected by linseed supply of $\mathrm{H}$ diets, except starch digestion, which increased $\left(P_{L}=0.03\right.$; Table 3$)$. Total-tract digestibility of all nutrients was unaffected by linseed supply of $\mathrm{H}$ diets (Table 3). Increasing linseed supply decreased linearly daily $\mathrm{CH}_{4}$ emission $(\mathrm{g} / \mathrm{d})$ in cows fed $\mathrm{H}$ diets from 486 to $289 \mathrm{~g} / \mathrm{d}$ for H0 to H15 $\left(P_{L}<0.01\right.$; Table 4). Expressed in grams per kilogram of DMI, the extent of the decrease in $\mathrm{CH}_{4}$ was, respectively, $-7,-15$, and $-38 \%$ with $\mathrm{H} 5, \mathrm{H} 10$, and $\mathrm{H} 15$ compared with $\mathrm{H} 0$, the decrease being more important for diets supplied with $15 \%$ of extruded linseed. The same significant response to increasing supply of extruded linseed was observed for $\mathrm{CH}_{4}$ emission expressed in proportion of GE intake $\left(P_{L}<0.01\right.$ and $\left.P_{Q}=0.03\right)$, per kilogram of nutrient digested $\left(P_{L}<0.01\right)$, and per kilogram of milk or FPCM $\left(0.03 \leq P_{L} \leq 0.02\right)$.

The effect of linseed supply on rumen fermentation and protozoa parameters was similar at both sampling times (sampling time $\times$ diet interaction not significant). Rumen $\mathrm{pH}$, total VFA, and $\mathrm{N}^{-\mathrm{NH}_{3}}$ concentrations were similar among $\mathrm{H}$ diets (Table 5). Acetate (C2) proportions were similar with increasing linseed supply, whereas propionate (C3) and butyrate (C4) proportions were affected $\left(P_{L}=0.02\right)$, involving a significant decrease in $\mathrm{C} 2 / \mathrm{C} 3$ and $(\mathrm{C} 2+\mathrm{C} 4) / \mathrm{C} 3$ ratios $\left(P_{L} \leq 0.04\right)$. For protozoa, increasing linseed supply linearly depressed their total numbers from -15 to $-40 \%$ on average for $\mathrm{H} 5$ to $\mathrm{H} 15$ compared with $\mathrm{H} 0\left(P_{L}\right.$ $<0.01$; Table 5). The concentration of the 3 cellulolytic bacteria in the liquid and solid phases of the rumen content was unaffected before feeding by linseed supply of $\mathrm{H}$ diet; only $F$. succinogenes tended to decrease in the solid phase $\left(P_{L}=0.06\right.$; Table 6$)$. The concentration of methanogens was unaffected by linseed supply in the liquid phase and tended to be lower for H10 compared with other diets in the solid phase $\left(P_{Q}=0.06\right.$; Table 6$)$.

\section{Experiment 2}

Body weight of cows fed CS diets did not change during experiment 2 (initial and final BW: $668 \pm 95.7$ and $665 \pm 108.9 \mathrm{~kg}$ ). Increasing supply of extruded linseed in the corn silage-based diets did not significantly modify intake of DM, OM, NDF, and N (Table

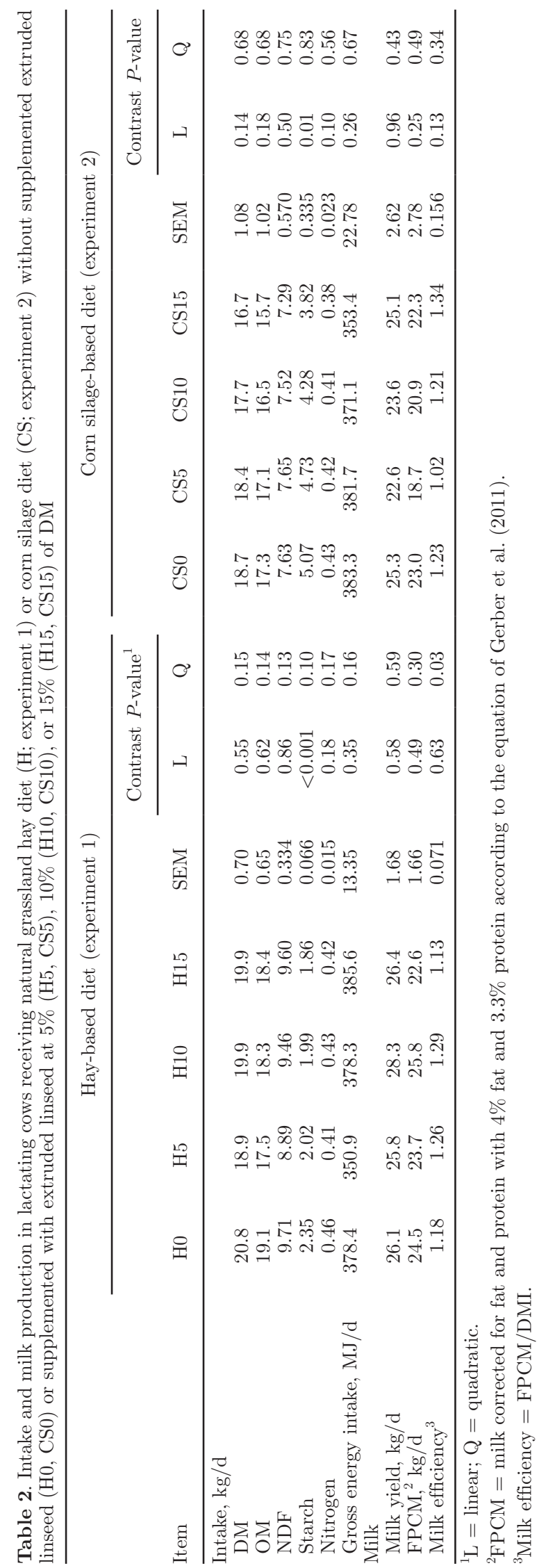

Journal of Dairy Science Vol. 99 No. 5, 2016 
득 Table 3. Intake, rumen and total-tract digestibility in lactating cows receiving natural grassland hay diet (H; experiment 1) or corn silage diet (CS; experiment 2) without supplemented extruded linseed (H0, CS0) or supplemented with extruded linseed at 5\% (H5, CS5), 10\% (H10, CS10), or 15\% (H15, CS15) of DM

\begin{tabular}{|c|c|c|c|c|c|c|c|c|c|c|c|c|c|c|}
\hline \multirow[b]{3}{*}{ Item } & \multicolumn{7}{|c|}{ Hay-based diet (experiment 1) } & \multicolumn{7}{|c|}{ Corn silage-based diet (experiment 2) } \\
\hline & \multirow[b]{2}{*}{ H0 } & \multirow[b]{2}{*}{ H5 } & \multirow[b]{2}{*}{ H10 } & \multirow[b]{2}{*}{ H15 } & \multirow[b]{2}{*}{ SEM } & \multicolumn{2}{|c|}{ Contrast $P$-value ${ }^{1}$} & \multirow[b]{2}{*}{ CS0 } & \multirow[b]{2}{*}{ CS5 } & \multirow[b]{2}{*}{ CS10 } & \multirow[b]{2}{*}{ CS15 } & \multirow[b]{2}{*}{ SEM } & \multicolumn{2}{|c|}{ Contrast $P$-value } \\
\hline & & & & & & $\mathrm{L}$ & $\mathrm{Q}$ & & & & & & $\mathrm{L}$ & $\mathrm{Q}$ \\
\hline \multicolumn{15}{|l|}{$\mathrm{DM}$} \\
\hline Rumen digestibility, ${ }^{2} \%$ & 35.1 & 37.6 & 35.6 & 33.8 & 4.03 & 0.73 & 0.57 & 38.5 & 41.2 & 42.2 & 29.1 & 4.47 & 0.27 & 0.16 \\
\hline Total-tract digestibility, $\%$ & 70.5 & 68.8 & 70.5 & 69.8 & 0.84 & 0.89 & 0.58 & 69.2 & 67.8 & 66.6 & 65.4 & 1.84 & 0.16 & 0.94 \\
\hline \multicolumn{15}{|l|}{ OM } \\
\hline Rumen digestibility, \% & 43.7 & 47.0 & 44.4 & 43.6 & 3.43 & 0.84 & 0.53 & 44.3 & 48.0 & 49.1 & 36.3 & 4.38 & 0.33 & 0.13 \\
\hline Total-tract digestibility, $\%$ & 72.1 & 70.5 & 72.1 & 71.4 & 0.84 & 0.92 & 0.61 & 70.4 & 69.3 & 68.2 & 67.3 & 1.84 & 0.22 & 0.98 \\
\hline \multicolumn{15}{|l|}{ NDF } \\
\hline Rumen digestibility, \% & 53.3 & 59.9 & 61.7 & 57.0 & 4.76 & 0.57 & 0.28 & 55.7 & 56.1 & 50.4 & 44.4 & 6.41 & 0.28 & 0.67 \\
\hline Total-tract digestibility, \% & 61.4 & 60.8 & 63.5 & 61.9 & 1.29 & 0.45 & 0.66 & 57.8 & 55.5 & 50.1 & 49.3 & 2.76 & 0.05 & 0.78 \\
\hline \multicolumn{15}{|l|}{ Starch } \\
\hline Rumen digestibility, \% & 65.9 & 77.2 & 78.3 & 84.9 & 4.51 & 0.03 & 0.62 & 69.3 & 83.1 & 85.8 & 72.6 & 3.22 & 0.46 & 0.010 \\
\hline Total-tract digestibility, \% & 97.5 & 96.9 & 97.5 & 97.7 & 0.96 & 0.45 & 0.29 & 90.8 & 92.8 & 93.5 & 93.5 & 0.61 & 0.009 & 0.09 \\
\hline \multicolumn{15}{|l|}{ Nitrogen } \\
\hline NAN duodenal flow/N intake, $\%$ & 1.22 & 1.16 & 1.18 & 1.17 & 0.088 & 0.64 & 0.73 & 0.95 & 0.97 & 0.84 & 0.99 & 0.065 & 0.98 & 0.39 \\
\hline Total-tract digestibility, \% & 67.3 & 67.1 & 66.0 & 67.4 & 0.70 & 0.78 & 0.31 & 65.9 & 65.7 & 67.3 & 67.5 & 1.78 & 0.46 & 0.89 \\
\hline
\end{tabular}

${ }^{1} \mathrm{~L}=$ linear; $\mathrm{Q}=$ quadratic.

${ }^{2}$ Rumen digestibility $=$ apparent rumen digestibility.

Table 4. Methane emission in lactating cows receiving natural grassland hay diet (H; experiment 1) or corn silage diet (CS; experiment 2) without supplemented extruded linseed (H0, CS0) or supplemented with extruded linseed at 5\% (H5, CS5), 10\% (H10, CS10), or 15\% (H15, CS15) of DM

\begin{tabular}{|c|c|c|c|c|c|c|c|c|c|c|c|c|c|c|}
\hline \multirow[b]{3}{*}{ Item } & \multicolumn{7}{|c|}{ Hay-based diet (experiment 1) } & \multicolumn{7}{|c|}{ Corn silage-based diet (experiment 2) } \\
\hline & \multirow[b]{2}{*}{ H0 } & \multirow[b]{2}{*}{ H5 } & \multirow[b]{2}{*}{ H10 } & \multirow[b]{2}{*}{ H15 } & \multirow[b]{2}{*}{ SEM } & \multicolumn{2}{|c|}{ Contrast $P$-value ${ }^{1}$} & \multirow[b]{2}{*}{ CS0 } & \multirow[b]{2}{*}{ CS5 } & \multirow[b]{2}{*}{ CS10 } & \multirow[b]{2}{*}{ CS15 } & \multirow[b]{2}{*}{ SEM } & \multicolumn{2}{|c|}{ Contrast $P$-value } \\
\hline & & & & & & $\mathrm{L}$ & $\mathrm{Q}$ & & & & & & $\mathrm{L}$ & $\mathrm{Q}$ \\
\hline $\mathrm{CH}_{4}, \mathrm{~g} / \mathrm{d}$ & 485.6 & 411.2 & 394.6 & 289.5 & 29.90 & 0.002 & 0.58 & 354.3 & 332.7 & 306.8 & 206.8 & 36.24 & 0.006 & 0.17 \\
\hline $\mathrm{CH}_{4}, \%$ of gross energy intake & 7.1 & 6.5 & 5.8 & 4.1 & 0.42 & 0.002 & 0.03 & 5.0 & 4.8 & 4.5 & 3.2 & 0.32 & 0.003 & 0.09 \\
\hline $\mathrm{CH}_{4}, \mathrm{~g} / \mathrm{kg}$ of DM intake & 23.4 & 21.8 & 19.9 & 14.6 & 1.45 & 0.005 & 0.25 & 18.8 & 18.0 & 17.3 & 12.3 & 1.26 & 0.004 & 0.08 \\
\hline $\mathrm{CH}_{4}, \mathrm{~g} / \mathrm{kg}$ of $\mathrm{OM}$ intake & 25.5 & 23.7 & 21.5 & 15.8 & 1.56 & 0.004 & 0.24 & 20.3 & 19.4 & 18.5 & 13.1 & 1.34 & 0.004 & 0.09 \\
\hline $\mathrm{CH}_{4}, \mathrm{~g} / \mathrm{kg}$ of NDF intake & 49.9 & 46.4 & 41.7 & 29.8 & 3.07 & 0.003 & 0.22 & 46.2 & 43.5 & 40.5 & 28.2 & 2.53 & 0.002 & 0.10 \\
\hline $\mathrm{CH}_{4}, \mathrm{~g} / \mathrm{kg}$ of digested DM & 33.3 & 31.7 & 28.2 & 20.9 & 2.56 & 0.006 & 0.23 & 27.2 & 26.5 & 26.1 & 18.9 & 2.08 & 0.02 & 0.11 \\
\hline $\mathrm{CH}_{4}, \mathrm{~g} / \mathrm{kg}$ of digested $\mathrm{OM}$ & 35.4 & 33.7 & 29.9 & 22.1 & 2.25 & 0.005 & 0.22 & 28.9 & 27.9 & 27.3 & 19.6 & 2.18 & 0.02 & 0.18 \\
\hline $\mathrm{CH}_{4}, \mathrm{~g} / \mathrm{kg}$ of digested NDF & 80.1 & 76.5 & 66.3 & 47.8 & 5.33 & 0.004 & 0.23 & 80.2 & 78.3 & 81.9 & 58.2 & 8.02 & 0.07 & 0.14 \\
\hline $\mathrm{CH}_{4}, \mathrm{~g} / \mathrm{kg}$ of milk & 18.6 & 16.9 & 14.2 & 11.7 & 1.60 & 0.02 & 0.81 & 14.1 & 15.6 & 13.6 & 9.1 & 1.65 & 0.04 & 0.08 \\
\hline $\mathrm{CH}_{4}, \mathrm{~g} / \mathrm{kg}$ of $\mathrm{FPCM}^{2}$ & 19.8 & 17.8 & 15.5 & 13.6 & 1.73 & 0.03 & 0.96 & 15.4 & 18.7 & 15.4 & 10.3 & 2.35 & 0.04 & 0.04 \\
\hline
\end{tabular}

${ }^{1} \mathrm{~L}=$ linear; $\mathrm{Q}=$ quadratic.

${ }^{2} \mathrm{FPCM}=$ milk corrected for fat and protein with $4 \%$ fat and $3.3 \%$ protein according to the equation of Gerber et al. (2011). 
Table 5. Rumen $\mathrm{pH}$, fermentative parameters and protozoa concentration in lactating cows receiving natural grassland hay (H; experiment 1) or corn silage (CS; experiment 2) diets without supplemented extruded linseed (H0, CS0) or supplemented with extruded linseed at 5\% (H5, CS5), 10\% (H10, CS10), or 15\% (H15, CS15) of DM

\begin{tabular}{|c|c|c|c|c|c|c|c|c|c|c|c|c|c|c|}
\hline \multirow[b]{3}{*}{ Item $^{1}$} & \multicolumn{7}{|c|}{ Hay-based diet (experiment 1) } & \multicolumn{7}{|c|}{ Corn silage-based diet (experiment 2) } \\
\hline & \multirow[b]{2}{*}{ H0 } & \multirow[b]{2}{*}{ H5 } & \multirow[b]{2}{*}{ H10 } & \multirow[b]{2}{*}{ H15 } & \multirow[b]{2}{*}{ SEM } & \multicolumn{2}{|c|}{ Contrast $P$-value ${ }^{2}$} & \multirow[b]{2}{*}{ CSO } & \multirow[b]{2}{*}{ CS5 } & \multirow[b]{2}{*}{ CS10 } & \multirow[b]{2}{*}{ CS15 } & \multirow[b]{2}{*}{ SEM } & \multicolumn{2}{|c|}{ Contrast $P$-value } \\
\hline & & & & & & $\mathrm{L}$ & $\mathrm{Q}$ & & & & & & $\mathrm{L}$ & $\mathrm{Q}$ \\
\hline $\mathrm{pH}$ & 6.42 & 6.44 & 6.46 & 6.46 & 0.083 & 0.71 & 0.96 & 6.60 & 6.58 & 6.77 & 6.85 & 0.09 & 0.03 & 0.71 \\
\hline Total VFA, $\mathrm{m} M$ & 106.0 & 107.7 & 112.3 & 110.3 & 6.31 & 0.53 & 0.77 & 96.4 & 95.2 & 95.8 & 88.2 & 3.55 & 0.15 & 0.38 \\
\hline Acetate (C2), \% & 63.4 & 62.6 & 62.8 & 62.1 & 0.69 & 0.24 & 0.95 & 64.5 & 63.0 & 60.9 & 59.8 & 0.80 & $<0.001$ & 0.82 \\
\hline Propionate (C3), \% & 20.2 & 21.2 & 21.3 & 22.6 & 0.79 & 0.02 & 0.82 & 20.0 & 21.2 & 22.3 & 25.5 & 0.64 & $<0.001$ & 0.08 \\
\hline Butyrate (C4), \% & 12.7 & 12.4 & 12.2 & 11.4 & 0.51 & 0.02 & 0.48 & 11.8 & 11.9 & 11.7 & 9.3 & 0.63 & 0.004 & 0.03 \\
\hline $\mathrm{C} 2 / \mathrm{C} 3$ & 3.19 & 3.01 & 2.99 & 2.82 & 0.133 & 0.04 & 0.98 & 3.36 & 3.05 & 2.89 & 2.44 & 0.102 & $<0.001$ & 0.49 \\
\hline$(\mathrm{C} 2+\mathrm{C} 4) / \mathrm{C} 3$ & 3.83 & 3.60 & 3.58 & 3.34 & 0.166 & 0.02 & 0.96 & 3.94 & 3.61 & 3.41 & 2.80 & 0.113 & $<0.001$ & 0.19 \\
\hline $\mathrm{N}-\mathrm{NH}_{3}, \mathrm{mg} / \mathrm{L}$ & 100.0 & 95.0 & 97.1 & 111.4 & 14.81 & 0.52 & 0.45 & 117.7 & 110.9 & 113.6 & 102.1 & 11.05 & 0.31 & 0.82 \\
\hline \multicolumn{15}{|c|}{ Protozoa, $\log _{10}$ cells $/ \mathrm{mL}$} \\
\hline Total & 5.61 & 5.55 & 5.55 & 5.38 & 0.045 & 0.002 & 0.24 & 5.68 & 5.59 & 5.44 & 4.73 & 0.103 & $<0.001$ & 0.002 \\
\hline Entodiniomorphs & 5.60 & 5.54 & 5.54 & 5.37 & 0.045 & 0.003 & 0.23 & 5.68 & 5.58 & 5.44 & 4.73 & 0.103 & $<0.001$ & 0.003 \\
\hline Holotrichs & 3.85 & 3.73 & 3.68 & 3.61 & 0.103 & 0.02 & 0.62 & 1.81 & 2.66 & 1.87 & 0.77 & 0.642 & 0.08 & 0.06 \\
\hline
\end{tabular}

${ }^{1}$ Average data for the 2 sampling times $(0$ and $2.5 \mathrm{~h}$ after feeding). No sampling time $\times$ diet interactions were found for any of the variables listed except for total VFA in diets CS $\left(P_{L}<0.01\right.$ and $P_{Q}=0.65$ at $0 \mathrm{~h} ; P_{L}=0.13$ and $P_{Q}=0.42$ at $\left.2.5 \mathrm{~h}\right)$.

${ }^{2} \mathrm{~L}=$ linear; $\mathrm{Q}=$ quadratic.

Table 6. Rumen methanogens and cellulolytic bacteria concentrations ${ }^{1}$ in lactating cows receiving natural grassland hay (H; experiment 1) or corn silage (CS; experiment 2) diet without supplemented extruded linseed (H0, CS0) or supplemented with extruded linseed at 5\% (H5, CS5), 10\% (H10, CS10), or 15\% (H15, CS15) of DM

\begin{tabular}{|c|c|c|c|c|c|c|c|c|c|c|c|c|c|c|}
\hline \multirow[b]{3}{*}{ Item $^{1}$} & \multicolumn{7}{|c|}{ Hay-based diet (experiment 1) } & \multicolumn{7}{|c|}{ Corn silage-based diet (experiment 2) } \\
\hline & \multirow[b]{2}{*}{ H0 } & \multirow[b]{2}{*}{ H5 } & \multirow[b]{2}{*}{ H10 } & \multirow[b]{2}{*}{ H15 } & \multirow[b]{2}{*}{ SEM } & \multicolumn{2}{|c|}{$\begin{array}{l}\text { Contrast } \\
P \text {-value }\end{array}$} & \multirow[b]{2}{*}{ CS0 } & \multirow[b]{2}{*}{ CS5 } & \multirow[b]{2}{*}{ CS10 } & \multirow[b]{2}{*}{ CS15 } & \multirow[b]{2}{*}{ SEM } & \multicolumn{2}{|c|}{ Contrast $P$-value } \\
\hline & & & & & & $\mathrm{L}$ & $\mathrm{Q}$ & & & & & & $\mathrm{L}$ & Q \\
\hline \multicolumn{15}{|c|}{ Methanogens, $\log _{10} m c r A$ copies $/ \mu \mathrm{g}$ of DNA } \\
\hline Liquid & 7.32 & 7.29 & 7.25 & 7.30 & 0.048 & 0.41 & 0.69 & 8.42 & 8.44 & 8.20 & 7.95 & 0.074 & 0.66 & 0.17 \\
\hline Solid & 7.17 & 7.16 & 7.08 & 7.19 & 0.032 & 0.87 & 0.06 & 8.23 & 8.25 & 8.17 & 8.29 & 0.084 & 0.78 & 0.58 \\
\hline \multicolumn{15}{|c|}{ Cellulolytic bacteria, $\log _{10} \mathrm{rrs}$ copies/ $\mu \mathrm{g}$ of DNA } \\
\hline Liquid & 7.15 & 7.14 & 7.21 & 7.28 & 0.089 & 0.14 & 0.55 & 7.08 & 6.82 & 6.42 & 6.94 & 0.286 & 0.15 & 0.67 \\
\hline Solid & 7.00 & 6.86 & 6.65 & 6.77 & 0.094 & 0.06 & 0.18 & 7.37 & 7.02 & 6.70 & 6.70 & 0.424 & 0.26 & 0.68 \\
\hline \multicolumn{15}{|c|}{ Ruminococcus flavefaciens } \\
\hline Liquid & 5.82 & 5.96 & 5.99 & 6.02 & 0.103 & 0.10 & 0.47 & 5.84 & 6.27 & 5.96 & 6.19 & 0.226 & 0.67 & 0.17 \\
\hline Solid & 6.25 & 6.36 & 6.55 & 6.43 & 0.182 & 0.37 & 0.50 & 7.78 & 7.98 & 7.86 & 7.97 & 0.163 & 0.53 & 0.80 \\
\hline \multicolumn{15}{|c|}{ Ruminococcus albus } \\
\hline Liquid & 5.71 & 5.79 & 5.78 & 5.90 & 0.56 & 0.88 & 0.59 & 6.12 & 6.27 & 6.40 & 6.30 & 0.202 & 0.67 & 0.17 \\
\hline Solid & 5.36 & 5.44 & 5.48 & 5.39 & 0.158 & 0.77 & 0.46 & 5.93 & 6.62 & 6.43 & 6.27 & 0.161 & 0.29 & 0.04 \\
\hline
\end{tabular}

or ${ }^{1}$ Data from different fractions of the rumen content (liquid and solid phase) sampled before feeding $(0 \mathrm{~h})$.

N $\quad{ }^{2} \mathrm{~L}=$ linear; $\mathrm{Q}=$ quadratic. 
2 ), even though a numerical and linear decrease was observed for DM intake from 18.7 to 16.7 for CS0 to CS15. Intake of starch decreased linearly with linseed supply $\left(P_{L}=0.01\right)$. Milk yield and FPCM were similar in diets based on corn silage as well as milk efficiency (Table 2).

Rumen digestibility of DM, OM, and NDF, and NAN duodenal flow were similar among CS diets, whereas starch digestion increased in the rumen, particularly for CS5 and CS10 compared with C0 and CS15 $\left(P_{Q}=0.01\right.$; Tables 3 ). In the total tract, NDF digestion decreased with linseed supply (from 57.8 to $49.3 \%$ for CS0 to CS15; $P_{L}=0.05$ ), which is related to the numerical decline in NDF digestion in the rumen. Total-tract starch digestion was higher for diets supplemented with linseed compared with CS0 $\left(P_{L}<0.01\right.$ and $P_{Q}=0.09$; Table 3).

Increasing linseed supply decreased daily $\mathrm{CH}_{4}$ emission $(\mathrm{g} / \mathrm{d})$ from 354 to $207 \mathrm{~g} / \mathrm{d}$ for CS0 to CS15 ( $P_{L}$ $<0.01$; Table 4). Compared with CS0, the extent of decrease in $\mathrm{CH}_{4}$ expressed per kilogram of DMI was -4 and $-8 \%$ with CS5 and CS10 and was more substantial $(-34 \%)$ with $\operatorname{CS} 15\left(P_{L}<0.01\right.$ and $\left.P_{Q}=0.08\right)$. The same significant response to increasing supply of extruded linseed was observed for $\mathrm{CH}_{4}$ output expressed in proportion of GE intake $\left(P_{L}<0.01\right.$ and $\left.P_{Q}=0.09\right)$, per kilogram of nutrient digested $\left(0.02 \leq P_{L} \leq 0.07\right)$, and per kilogram of milk or kilogram of FPCM $\left(P_{L}=\right.$ 0.04 and $\left.0.04 \leq P_{Q} \leq 0.08\right)$.

Rumen $\mathrm{pH}$ increased with linseed supply in CS diets $\left(P_{L}=0.03\right)$ (Table 5). The effect of extruded linseed supply on the total VFA concentration in the rumen differed between the 2 sampling times (sampling time $\times$ diet interaction: $P<0.001$; data not shown); VFA concentration decreased significantly before feeding with linseed supply ( $-26 \mathrm{mM}$ between CS0 and CS15; $\left.P_{L}<0.01\right)$ and was unchanged $2.5 \mathrm{~h}$ after feeding. The main changes in VFA profiles were a decrease in acetate $\left(P_{L}<0.001\right)$ and butyrate proportions $\left(P_{L}<0.001\right.$ and $\left.P_{Q}=0.03\right)$ and an increase in propionate proportion $\left(P_{L}<0.001\right)$, which resulted in lower ratios of acetate:propionate and (acetate + butyrate):propionate $\left(P_{L}<0.001\right)$ with linseed supply (Table 5$)$. No change in $\mathrm{N}-\mathrm{NH}_{3}$ concentration was observed among diets. Total protozoa and entodiniomorph concentrations in the rumen decreased with increasing linseed supply for CS diets $\left(P_{L} \leq 0.001\right.$ and $P_{Q} \leq 0.01$; Table 6$)$.

The concentration of the 3 cellulolytic bacteria in the liquid and solid phases of the rumen content was unaffected by linseed supply before feeding, except that of $R$. albus, which increased for CS5 and CS10 compared with CS0 and CS15 $\left(P_{Q}=0.04\right)$ in the solid phase. The concentration of methanogens was similar among CS diets in both phases of the rumen content.

\section{DISCUSSION}

This is the first report on the dose-response effect of extruded linseed supply in diets based on hay or corn silage on enteric $\mathrm{CH}_{4}$ emissions in dairy cows. Quantitative digestion in the rumen and the total-tract as well as rumen fermentation and microbial mechanisms of methanogenesis observed in both experiments were also considered. The interaction between linseed FA and the type of forage was not assessed statistically in this work because the 2 forages were studied in 2 different experiments. However, this point is discussed in the light of the available literature.

\section{Effect of Increasing Linseed Supply on Digestibility and Rumen Processes}

The OM digestibility of $\mathrm{H}$ and $\mathrm{CS}$ diets was not significantly decreased by linseed supply, although it was numerically lower by 8.0 and 3.1 percentage points between CS0 and CS15 for rumen and total-tract digestibility, respectively. This decrease was accompanied by a numerical decrease in OM intake $(-1.6 \mathrm{~kg}$ between CS0 and CS15), which resulted in a decrease in digestible $\mathrm{OM}$ intake, without negative consequences for milk production or animal BW. This trend might have become significant if more animals had been used in these experiments. Linseed supply (3-4\% FA) in 50 to $55 \%$ silage-based diets had no effect on OM digestibility in dairy cows (Gonthier et al., 2004; Benchaar et al., 2012) or in dry cows fed $2.6 \%$ linseed oil in a $50 \%$ hay-based diet (Guyader et al., 2015). Others have also reported no change in OM digestibility with 4 to $5 \%$ linseed FA supply, although the numerical decrease was greater with corn silage-based than with red clover silage-based diets in dairy cows (4\% linseed oil; Benchaar et al., 2015) and with barley silage-based than with hay-based diets in dry cows $(5 \%$ added FA from crude linseed; Chung et al., 2011). Taken together, these results show that an increase of more than 4 to $5 \%$ of FA from linseed may present a risk of reduction of OM digestibility, at least with cereal silage-based diets, as previously shown (Martin et al., 2008).

In the present study, the absence of a significant decrease in OM digestibility for CS diets may be related to the opposite effects of linseed supplementation on NDF and starch digestibility in the total tract. Indeed, NDF digestibility linearly decreased with increasing linseed supply, whereas the opposite was observed for starch digestibility. With CS diets, the higher starch digestibility with linseed supply can be explained by a lower starch intake because starch is replaced by lipids. It has been shown that starch digestibility is decreased when the amount of corn ingested is excessive 
(Nozière et al., 2010). In the rumen, the trend toward a decrease in NDF digestibility with increasing linseed supply of CS diets is consistent with the preprandial decrease in VFA concentration. With $\mathrm{H}$ diets, neither NDF digestibility nor VFA concentration in the rumen was modified by linseed supply. In agreement with our results, the extent of rumen fermentation as reflected by VFA concentration was not affected by linseed supply for diets based on hay (Chung et al., 2011) or red clover silage-based diets (Benchaar et al., 2015), but was reduced for barley silage-based diets (Chung et al., 2011; Benchaar et al., 2015). In these 2 last studies, the decrease in rumen VFA concentration may also have been related to the decrease in the digestibility of the fiber fraction of diets.

Neither ruminal ammonia concentration nor duodenal NAN flow varied with lipid supply in our experiments. This confirms the general effect observed with lipids whatever their source (Doreau and Ferlay, 1995) and results obtained with linseed supply (Ueda et al., 2003). A decrease in ammonia could have been expected because of the decrease in protozoa, which is often associated with a decrease in protein degradation (Morgavi et al., 2008). In this experiment, the absence of change in ammonia suggests that protein metabolism in the rumen was not modified. Chung et al. (2011) and Guyader et al. (2015) also observed the absence of variation of ruminal ammonia and urinary $\mathrm{N}$ despite a decrease in protozoa when linseed was supplied in the diet. The changes in protozoa population may have been too small to result in changes in rumen protein metabolism.

Polyunsaturated FA have been shown to have a toxic effect on some rumen bacteria species, especially cellulolytic bacteria (Maia et al., 2007; Mao et al., 2010). This toxic effect of linseed FA on the concentrations of the 3 main cellulolytic bacteria species (F. succinogenes, $R$. albus, $R$. flavefaciens) was not observed in our work with $\mathrm{H}$ or CS diets. Therefore, the lower NDF rumen digestion in CS diets in response to linseed supply cannot be explained by a decline in cellulolytic bacteria number but a decrease in their fibrolytic activity can be supposed.

\section{Effect of Increasing Linseed Supply on Enteric Methane Emission and Rumen Processes}

The $\mathrm{CH}_{4}$ emission per kilogram of DM from published data (Beauchemin et al., 2009a) is close to the average value for the $\mathrm{H} 0$ diet and in the lower range of variation for the CS0 diet. The latter observation may be due to the high starch content of the CS diet. Daily $\mathrm{CH}_{4}$ emission decreased with increasing FA supply from linseed, confirming that lipid supplementation is one of the most effective dietary strategies in lowering enteric $\mathrm{CH}_{4}$ emission by ruminants (Martin et al., 2010; Grainger and Beauchemin, 2011; Hristov et al., 2013). The $\mathrm{CH}_{4}$-mitigating effect of extruded linseed $(2-3 \%$ added FA) persisted for up to $1 \mathrm{yr}$ in dairy cows fed diets based on grazed pasture $(80 \%)$ or grass silage $(60 \%$; Martin et al., 2011). However, the $\mathrm{CH}_{4}$-mitigating effect of linseed oil in dairy cows was not systematic, probably because of the low level of FA included in the diets in some studies (1-2\%; van Zijderveld et al., 2011; Livingstone et al., 2015).

We reported a linear effect of extruded linseed supply on $\mathrm{CH}_{4}$ yield $(\mathrm{g} / \mathrm{kg}$ of $\mathrm{DMI})$ with both types of forages. The decrease was greater with the highest FA supply than with the 2 other levels of supplementation $(-3.1,-3.2$, and $-6.7 \%$ per $1 \%$ added FA on average for the 2 diets supplemented with 1.8, 3.6, and $5.4 \%$ of FA, respectively). To our knowledge, the dose-response effect of dietary FA on methanogenesis in ruminants has never been studied with linseed and with only a few with other FA sources. A linear effect of FA supply on $\mathrm{CH}_{4}$ emission in cattle was reported with rapeseed oil (0, 5.4, 9.5\% added FA; Jentsch et al., 1972), and coconut oil $(0,1.3,2.7,3.3 \%$ added FA in Hollmann et al., 2012; 0, 1.3, 2.7, 4.6\% added FA in Jordan et al., 2006). A quadratic effect was reported with the highest supply of coconut oil in sheep $(0,3.5,7 \%$ added FA; Machmüller and Kreuzer, 1999). In their quantitative review of the literature, Grainger and Beauchemin (2011) reported a linear reduction in $\mathrm{CH}_{4}$ yield of dairy cattle with diets containing up to $80 \mathrm{~g}$ of total dietary FA/kg of DM. The relationship was not affected by the source of FA but differed between cattle and sheep.

The interaction effect between lipids and the nature of the forage in the diet on $\mathrm{CH}_{4}$ emission has seldom been studied. Chung et al. (2011) observed an effect of $5 \%$ added FA from crude linseed with barley silagebased but not with grass hay-based diets fed to dry cows (50:50). Benchaar et al. (2015) reported an effect of $4 \%$ linseed oil that was greater with corn silage (60:40) than with red clover silage in dairy cows. All of these results suggest that the effect of dietary linseed supply on enteric $\mathrm{CH}_{4}$ emission in cows appears to be modulated by the source of dietary forage source, and it appears to be greater with diets containing more starch and less fiber.

In our study, the dose-response curve of the effect of extruded linseed on methanogenesis was similar for $\mathrm{CH}_{4}$ emission expressed per kilogram of nutrient intake, per kilogram of digested nutrient, and per kilogram of milk. This suggests that $\mathrm{CH}_{4}$ emission variations with linseed FA cannot be explained by changes in intake, digestibility, or milk production. Milk efficiency ( $\mathrm{kg}$ of FPCM/DMI) was highest for H5 and H10 among 
the $\mathrm{H}$ diets, and did not vary among the CS diets, for unexplained reasons. The changes in net energy value due to FA addition was probably too limited to entail an increase in energy value of the diet.

A first explanation of the $\mathrm{CH}_{4}$-mitigating effect of FA is that, whatever their nature, they decrease the amount of OM fermented in the rumen if they replace a proportion of dietary carbohydrates, as was the case in our experiments. The biohydrogenation process in the rumen of added PUFA from linseed may also help to decrease methanogenesis, but the hydrogen sink function of PUFA in the rumen was estimated to be negligible (i.e., 1-2\%) in studies based on stoichiometric (Czerkawski, 1986) and modeling (Mills et al., 2001) approaches. The specific effect of linseed FA is generally related to changes in rumen microbes and associated fermentation patterns. Concerning rumen protozoa, their concentration was systematically reduced by linseed supply. This effect was linear in $\mathrm{H}$ diets and both linear and quadratic in CS diets, which may explain the greater decrease in methanogenesis with CS15 than with CS5 and CS10 compared with CS0. This adverse effect of FA from linseed on rumen protozoa is classical but not systematic. It was reported with similar levels of ground linseed in barley silage-based diets ( $-82 \%$, Chung et al., 2011), linseed oil in hay-based diets $(-52 \%$, Guyader et al., 2015) fed to nonlactating cows, and linseed oil in corn silage-based diets fed to dairy cows ( $-78 \%$, Benchaar et al., 2015). In contrast, linseed oil supply (up to 4\%) in silage-based diets had no effect on the total number or the genera distribution of protozoa in dairy cows (Benchaar et al., 2012). Protozoa act as physical hosts for methanogens and during fermentation produce a high quantity of $\mathrm{H}_{2}$, which is used by methanogens to reduce $\mathrm{CO}_{2}$ to $\mathrm{CH}_{4}$ (Morgavi et al., 2010). Consequently, the toxic effect of linseed FA on protozoa, associated with lower $\mathrm{H}_{2}$ availability to methanogens, appears to be involved in $\mathrm{CH}_{4}$ mitigation in ruminants. This confirms recent findings from a meta-analysis of the literature (Guyader et al., 2014). Abundance of rumen methanogens was not affected by linseed supply in the $\mathrm{H}$ and CS diets. In previous studies in which methanogenesis was reduced, rumen methanogens were unaffected by a supply of $3 \%$ FA from extruded linseed in dairy cows (Martin et al., 2011), whereas their number decreased in dry cows supplemented with $4 \%$ linseed oil (Guyader et al., 2015). All these results support the view that the number of rumen methanogens is not the key factor affecting $\mathrm{CH}_{4}$ emission (Morgavi et al., 2010). A modulation of the activity and diversity of methanogens might be responsible for the $\mathrm{CH}_{4}$ mitigating effect of linseed FA, as observed in bulls fed a starch-rich diet (Popova et al., 2011).
Reported effects of linseed supply on rumen fermentation parameters remain inconsistent in the literature. An increase in the proportion of propionate in response to 2 to $4 \%$ linseed FA supplementation was reported with diets based on hay in dry cows (Guyader et al., 2015) or on corn and grass silages in dairy cows (Gonthier et al., 2004). Others authors have reported no effect of different linseed forms (rolled, extruded, oil) on rumen VFA composition in dairy cows fed grass silage (Martin et al., 2011) or corn silage (Doreau et al., 2009). Direct comparisons in dry cows (Chung et al., 2011) or dairy cows (Benchaar et al., 2015) indicate that the effect of linseed FA supply on rumen VFA composition varied with the nature of the dietary forage. No changes in VFA composition were reported with diets based on hay or red clover silage, whereas the proportion of propionate increased with diets based on cereal silages. In the present work, increasing the linseed supply changed rumen VFA composition by increasing propionate at the expense of butyrate in $\mathrm{H}$ diets and at the expense of butyrate and acetate in CS diets. This shift of rumen fermentation patterns toward the $\mathrm{H}_{2}$-consuming pathway (propionate) at the expense of the $\mathrm{H}_{2}$-producing pathway (acetate and butyrate) may indicate an $\mathrm{H}_{2}$ excess due to the diminished $\mathrm{CH}_{4}$ production (Janssen, 2010) and may be related to the decline in protozoa observed with linseed supply in both diets. This is supported by Morgavi et al. (2008), who reported an increase in propionate production with a concomitant decrease in butyrate production in the rumen of sheep without protozoa compared with faunated sheep.

\section{CONCLUSIONS}

The effect of increasing extruded linseed FA supply on enteric $\mathrm{CH}_{4}$ emission, digestibility, and rumen function was studied in dairy cows fed diets based on hay or corn silage in 2 separate experiments. Extruded linseed efficiently and linearly reduced $\mathrm{CH}_{4}$ emission in both experiments without altering intake, digestibility, or milk production with the hay-based diets. With the corn silage-based diets, intake and fiber digestibility decreased numerically with the highest linseed FA supply. The decrease in rumen protozoa number and the shift of fermentation toward propionate production appear to be related to the $\mathrm{CH}_{4}$ mitigating effect of linseed with the hay- and corn silage-based diets. The energetic benefits of decreased $\mathrm{CH}_{4}$ emission improved the milk efficiency of cows fed hay-based diets supplemented with the lowest linseed FA levels but not that of cows fed corn silage-based diets. Lower $\mathrm{CH}_{4}$ emission from dairy cows fed linseed helps to limit the negative environmental impact of ruminant livestock. 


\section{ACKNOWLEDGMENTS}

The authors acknowledge the assistance of the staff of the staff of the animal experimental facilities "Les Cèdres" (UMR1213 Herbivores, INRA, Saint-GenèsChampanelle, France), particularly F. Anglard, D. Roux, and S. Rudel for animal care, L. Genestoux and S. Laverroux (UMR1213 Herbivores) for help in the laboratory and statistical analyses. The authors want to honor the memory of their colleague in charge of protozoa counting, Michel Fabre, for his good mood and great availability at work. The work was performed with the financial support of the French National Research Agency under the "Programme National de Recherche en Alimentation et Nutrition Humaine" (project ANR05-PNRA-017-04, titled Transqual (Trans fatty acids from dairy sources: a comparison of the biological effect compared to trans fatty acids of technological origin).

\section{REFERENCES}

AOAC International. 1997. Official Methods of Analysis. 16th ed. AOAC International, Gaithersburg, MD.

Beauchemin, K. A., T. A. McAllister, and S. M. McGinn. 2009a. Dietary mitigation of enteric methane from cattle. CABI Rev. 4:1-18.

Beauchemin, K. A., S. M. McGinn, C. Benchaar, and L. Holtshausen. 2009b. Crushed sunflower, flax, or canola seeds in lactating dairy cow diets: Effects on methane production, rumen fermentation, and milk production. J. Dairy Sci. 92:2118-2127.

Benchaar, C., F. Hassanat, R. Martineau, and R. Gervais. 2015. Linseed oil supplementation to dairy cows fed diets based on red clover silage or corn silage: Effects on methane production, rumen fermentation, nutrient digestibility, $\mathrm{N}$ balance, and milk production. J. Dairy Sci. 98:7993-8008.

Benchaar, C., G. A. Romero-Pérez, P. Y. Chouinard, F. Hassanat, M. Eugène, H. V. Petit, and C. Côrtes. 2012. Supplementation of increasing amounts of linseed oil to dairy cows fed total mixed rations: Effects on digestion, ruminal fermentation characteristics, protozoal populations, and milk fatty acid composition. J. Dairy Sci. 95:4578-4590.

Chung, Y. H., M. L. He, S. M. McGinn, T. A. McAllister, and K. A. Beauchemin. 2011. Linseed suppresses enteric methane emissions from cattle fed barley silage, but not from those fed grass hay. Anim. Feed Sci. Technol. 167:321-329.

Czerkawski, J. W. 1986. An Introduction to Rumen Studies. Pergamon Press, Oxford, UK.

Doreau, M., E. Aurousseau, and C. Martin. 2009. Effects of linseed lipids fed as rolled seeds, extruded seeds or oil on organic matter and protein digestion in cows. Anim. Feed Sci. Technol. 130:187-196.

Doreau, M., D. Bauchart, and Y. Chilliard. 2011. Enhancing fatty acid composition of milk and meat through animal feeding. Anim. Prod. Sci. 51:19-29.

Doreau, M., and A. Ferlay. 1995. Effect of dietary lipids on nitrogen metabolism in the rumen: A review. Livest. Prod. Sci. 43:97-110.

Fanchone, A., P. Nozière, J. Portelli, B. Duriot, V. Largeau, and M. Doreau. 2013. Effects of nitrogen underfeeding and energy source on nitrogen ruminal metabolism, digestion and nitrogen partitioning in dairy cows. J. Anim. Sci. 91:895-906.

Ferlay, A., C. Martin, M. Doreau, and Y. Chilliard. 2013. Effects of incremental amounts of extruded linseed on the milk fatty acid composition of dairy cows receiving hay or corn silage. J. Dairy Sci. 96:6577-6595.

Gerber, P., T. Vellinga, C. Opio, and H. Steinfeld. 2011. Productivity gains and greenhouse gas emissions intensity in dairy systems. Livest. Sci. 139:100-108.
Gonthier, C., A. F. Mustafa, R. Berthiaume, H. V. Petit, R. Martineau, and D. R. Ouellet. 2004. Effects of feeding micronized and extruded flaxseed on ruminal fermentation and nutrient utilization by dairy cows. J. Dairy Sci. 87:1854-1863.

Grainger, C., and K. A. Beauchemin. 2011. Can enteric methane emissions from ruminants be lowered without lowering their production? Anim. Feed Sci. Technol. 167:308-320.

Guyader, J., M. Eugène, B. Meunier, M. Doreau, D. P. Morgavi, M. Silberberg, Y. Rochette, C. Gérard, C. Loncke, and C. Martin. 2015. Additive mitigating effect between dietary linseed oil and nitrate fed to cattle. J. Anim. Sci. 93:3564-3577.

Guyader, J., M. Eugène, P. Nozière, D. P. Morgavi, M. Doreau, and C. Martin. 2014. Influence of rumen protozoa on methane emissions in ruminants: A meta-analysis approach. Animal 8:1816-1825.

Hart, S. P., and C. E. Polan. 1984. Simultaneous extraction and determination of ytterbium and cobalt ethylenediaminetetracetate complex in feces. J. Dairy Sci. 67:888-896.

Hollmann, M., W. J. Powers, A. C. Fogiel, J. S. Liesman, N. M. Bello, and D. K. Beede. 2012. Enteric methane emissions and lactational performance of Holstein cows fed different concentrations of coconut oil. J. Dairy Sci. 95:2602-2615.

Hristov, A. N., J. Oh, J. Firkins, J. Dijkstra, E. Kebreab, G. Waghorn, H. P. S. Makkar, A. Adesogan, W. Yang, C. Lee, P. J. Gerber, B. Henderson, and J. M. Tricarico. 2013. Mitigation from methane and nitrous oxide emissions from animal operations. A review of enteric methane mitigation options. J. Anim. Sci. 91:5045-5069.

INRA (Institut National de la Recherche Agronomique). 2007. Alimentation des bovins, ovins et caprins. Besoins des Animaux - Valeur des aliments - Tables INRA 2007. Editions Quae, Versailles, France.

Janssen, P. H. 2010. Influence of hydrogen on rumen methane formation and fermentation balances through microbial growth kinetics and fermentation thermodynamics. Anim. Feed Sci. Technol. 160:1-22.

Jentsch, W., H. Wittenburg, and R. Schiemann. 1972. Die Verwertung der Futterenergie für die Milchproduction. 4. Untersuchungen über die Verwertung der Futterenergie bei Räpsöleinsatz. Arch. Tierernahr. 22:697-720.

Johnson, K. A., and D. E. Johnson. 1995. Methane emissions from cattle. J. Anim. Sci. 73:2483-2492.

Jordan, E., D. K. Lovett, M. Hawkins, J. J. Callan, and F. P. O'Mara. 2006. The effect of varying levels of coconut oil on intake, digestibility and methane output from continental cross beef heifers. Anim. Sci. 82:859-865.

Jouany, J. P. 1982. Volatile fatty acid and alcohol determination in digestive contents, silage juices, bacterial cultures and anaerobic fermentor contents. Sci. Aliments 2:131-144.

Jouany, J. P., and J. Senaud. 1982. Influence des ciliés du rumen sur la digestion des différents glucides chez les moutons. I. Utilisation des glucides pariétaux (cellulose, hemicellulose) et de l'amidon. Reprod. Nutr. Dev. 22:735-752.

Livingstone, K. M., D. J. Humphries, P. Kirton, K. E. Kliem, D I. Givens, and C. K. Reynolds. 2015. Effects of forage type and extruded linseed supplementation on methane production and milk fatty acid composition of lactating dairy cows. J. Dairy Sci. 98:4000-4011.

Machmüller, A., and M. Kreuzer. 1999. Methane suppression by coconut oil and associated effects on nutrient and energy balance in sheep. Can. J. Anim. Sci. 79:65-72.

Maia, M. R. G., L. C. Chaudhary, L. Figueres, and R. J. Wallace. 2007. Metabolism of polyunsaturated fatty acids and their toxicity to the microflora of the rumen. Antonie van Leeuwenhoek 91:303-314.

Mao, H. L., J. K. Wang, Y. Y. Zhou, and J. X. Liu. 2010. Effects of addition of tea saponins and soybean oil on methane production, fermentation and microbial population in the rumen of growing lambs. Livest. Sci. 129:56-62.

Martin, C., D. P. Morgavi, and M. Doreau. 2010. Methane mitigation in ruminants: from microbe to the farm scale. Animal 4:351-365.

Martin, C., D. Pomiès, A. Ferlay, Y. Rochette, B. Martin, Y. Chilliard, D. P. Morgavi, and M. Doreau. 2011. Methane output and rumen 
microbiota in dairy cows in response to long term supplementation with linseed or rapeseed of grass silage- or pasture-based diets. Proc. N.Z. Soc. Anim. Prod. 71:243-247.

Martin, C., J. Rouel, J. P. Jouany, M. Doreau, and Y. Chilliard. 2008. Methane output from dairy cows in response to dietary supplementation of crude linseed, extruded linseed or linseed oil. J. Anim. Sci. 86:2642-2650.

Mills, J. A. N., J. Dijkstra, A. Bannink, S. B. Cammell, E. Kebreab, and J. France. 2001. A mechanistic model of whole-tract digestion and methanogenesis in the lactating dairy cow: Model development, evaluation and application. J. Anim. Sci. 79:1584-1597.

Morgavi, D. P., E. Forano, C. Martin, and C. J. Newbold. 2010. Microbial ecosystem and methanogenesis in ruminants. Animal 4:1024-1036

Morgavi, D. P., J. P. Jouany, and C. Martin. 2008. Changes in methane emission and rumen fermentation parameters induced by refaunation in sheep. Aust. J. Exp. Agric. 48:69-72.

Mosoni, P., F. Chaucheyras-Durand, C. Bera-Maillet, and E. Forano. 2007. Quantification by real-time PCR of cellulolytic bacteria in the rumen of sheep after supplementation of a forage diet with readily fermentable carbohydrates: Effect of a yeast additive. J. Appl. Microbiol. 103:2676-2685.

Mosoni, P., C. Martin, E. Forano, and D. P. Morgavi. 2011. Long-term defaunation increases the abundance of cellulolytic ruminococci and methanogens but does not affect the bacterial and methanogen diversity in the rumen of sheep. J. Anim. Sci. 89:783-791.

Nozière, P., I. Ortigues-Marty, C. Loncke, and D. Sauvant. 2010. Carbohydrate quantitative digestion and absorption in ruminants: from feed starch and fibre to nutrients available for tissues. Animal 4:1057-1074
Popova, M., C. Martin, M. Eugène, M. M. Mialon, M. Doreau, and D. P. Morgavi. 2011. Effect of fibre- and starch-rich finishing diets on methanogenic Archaea diversity and activity in the rumen of feedlot bulls. Anim. Feed Sci. Technol. 166:113-121.

SAS Institute. 2003. User's guide: Statistics. Version 9.1 SAS Inst. Inc., Cary, NC.

Ueda, K., A. Ferlay, J. Chabrot, J. J. Loor, Y. Chilliard, and M. Doreau. 2003. Effect of linseed oil supplementation on ruminal digestion in dairy cows fed diets with different forage:concentrate ratios. J. Dairy Sci. 86:3999-4007.

Van Soest, P. J., J. B. Robertson, and B. A. Lewis. 1991. Methods for dietary fiber, neutral detergent fiber, and nonstarch polysaccharides in relation to animal nutrition. J. Dairy Sci. 74:3583-3597.

van Zijderveld, S. M., J. Dijkstra, H. B. Perdok, J. R. Newbold, and W. J. J. Gerrits. 2011. Dietary inclusion of diallyl disulfide, yucca powder, calcium fumarate, an extruded linseed product, or medium-chain fatty acids does not affect methane production in lactating dairy cows. J. Dairy Sci. 94:3094-3104.

Veysset, P., M. Lherm, and D. Bébin. 2010. Energy consumption, greenhouse gas emissions and economic performance assessment in French Charolais suckler cattle farms: Model-based analysis and forecasts. Agric. Syst. 103:41-50.

Weatherburn, M. W. 1967. Phenol-hypochlorite reaction for determination of ammonia. Anal. Chem. 39:971-973.

Williams, A. G., and G. S. Coleman. 1992. The Rumen Protozoa. Springer-Verlag, New York, NY.

Yu, Z., and M. Morrison. 2004. Improved extraction of PCR-quality community DNA from digesta and fecal samples. Biotechniques $36: 808-812$. 